Informasi - ISSN (p) 0126-o650; ISSN (e) 2502-3837

Vol. 5o, No. 2 (2020), pp. 165-176 doi: http://doi.org/10.21831/informasi.v5oi2.30149

\title{
The power of social media in BERLIBUR as new social movement in West Bandung Regency Indonesia
}

\author{
Meria Octavianti \\ Faculty of Communication Science, Universitas Padjadjaran, Indonesia \\ meria.octavianti@unpad.ac.id \\ Atalia Praratya \\ Faculty of Communication Science, Universitas Padjadjaran, Indonesia \\ atalia19001@mail.unpad.ac.id
}

Article History: Received 2020-02-12, Revised 2020-11-28, Accepted 2020-11-30

\begin{abstract}
Social media has a tremendous power to drive community participation in development. This is evidenced by Berlibur (bebersih keliling lembur) 'Cleaning Our Surroundings', a program that have been successfully held regularly by many communities in West Bandung Regency. Berlibur is a new social movement in West Bandung that is rooted from the concern of various communities about environmental cleanliness, particularly about the bad habit of littering. This article aims at looking into the most important thing igniting public participation and engaging them to Berlibur, so that the research result could be empirical data in developing and enhancing the initiative. This study employed qualitative method with case study approach to describe how the power of social media can drive community participation in this independent environmental cleaning up program. The results showed that the form and the content of social media as well as the character of the audience become the key factor in the success of communication of the initiators of Berlibur. Various communities with different backgrounds are united in Komunitas Lintas KBB 'All West Bandung Regency Communities' to collect garbage to positively exemplify and unconsciously grow the community awareness of throwing garbage properly.
\end{abstract}

Keywords: Social Media, New Social Movement, Community, Berlibur, Garbage Collection Movement 


\section{INTRODUCTION}

Berlibur is a word that is so familiar to Indonesian People. Etymologically, berlibur derives from the word libur, which means free from work and school. Therefore, berlibur is a verb of Indonesian language which means having a vacation of going somewhere (to have fun, to enjoy one's self, etc.) to spend holiday (Badan Pengembangan dan Pembinaan Bahasa, 2016). However, it is different for people who live in West Bandung Regency, West Java, Indonesia. Berlibur has another meaning for them. It is an acronym for Bebersih Keliling Lembur 'Cleaning Up Our Surroundings.' According to Rudy Praja, the coordinator of the program, it is a community-based cleanliness movement to clean up waste in certain places in West Bandung Regency.

Waste has indeed been a polemic that has not been optimally solved. Waste is basically leftover materials from a process, either production (industry) or consumption. Along with the times, the amount of waste, instead of decreasing, is even increasing. This is related to the lifestyle of modern people that are fading away from old traditions. Their lifestyle is synonymous with the production and consumption of hard-to-decompose goods. Thus, the leftover of these goods will be waste (Nugroho, 2017).

Many programs have been implemented by relevant government agencies to solve waste problem. In fact, in regard to waste management, the government of Indonesia has enacted a specific law, i.e. Law no. 18 Year 2008. The law, among others, states that the regional government should implement good, eco-friendly waste management. The regional government is authorized to establish policies and strategies for waste management. The law also explains community role in the regional waste management. However, again, the law is only a government regulation. Now the question is whether the regional government has established a policy and strategy for waste management. If they have, the question is whether it is only a discourse or implementation. The next question is whether the policy is supported and positively responded by the community so that they participate in. Evidence shows that waste is still an unsolved problem in West Bandung Regency.

Piles of garbage can be easily found in public places and along the protocol roads in the regency. This indicates that the existing waste management is still not able to increase public awareness of the danger of waste and, especially, to make the people live a clean, healthy life. The beauty of the city and the health of its people will be at stake if no adequate action is done to solve the problem.

Thus, the youth of West Bandung Regency from various communities took an initiative to make a program to not only make people realize the danger of waste, but also to encourage them to participate in the efforts to clean the environment. These young men, who previously had successfully conducted many environmental cleanup programs in order to commemorate World Cleanup Day in September 2018, thought that it was necessary to create a similar program on a regular basis, not only on certain days. They, who originally came from different communities, eventually agreed to unite and charter a joint community called Lintas Komunitas Kabupaten Bandung Barat 'All West Bandung Regency Communities,' and the first program of the community is Berlibur (bebersih keliling lembur) 'Cleaning Up Our Surroundings.' The youth's movement is a collective action to realize common interest called social movement (Giddens, 1993). Social movement is a movement to realize common interest through collective action outside the scope of established institutions (Suharko, 2005).

Berlibur started on January 6, 2019 in Kecamatan Parongpong. Ruby, a young woman who live in Kecamatan Parongpong with a background of being a member of environmental and adventure organization, felt that it was her call to prepare the program. Even though it was initiated by three people and prepared only in a week, public participation was extraordinary. 
According to her, who was then the secretary of Berlibur in Kecamatan Parongpong, around 330 people from 41 communities participated in the first event. They were able to clean 6 tons of waste around Curug Cimahi, Parongpong (Maharsi, 2019). The extraordinary attention from the youth of West Bandung encouraged the initiators to continuously improve the following events in the months to come.

Berlibur becomes a regular program of Lintas Komunitas KBB in all 16 kecamatan 'districts' of KBB for 12 months in 2019. As of the writing of this paper, August 2019, it has been conducted in 9 kecamatan: Parongpong, Lembang, Batujajar, Ngamprah, Cipongkor, Sindangkerta, Saguling, Cipatat, and Padalarang. According to Rudy Praja, the coordinator, the average number of participants is 300 per event. However, in the latest event, held in Kecamatan Padalarang, the number of participants was around 800 from 65 communities in KBB (Sari, 2019). This is remarkable, given the fact that this program was initiated by a few young men who are concerned with waste problem, but now it has a great impact that make people realize the importance to keep their surroundings clean. The movement by Lintas Komunitas KBB, according to Singh (2001), is an environmental movement that is part of the New Social Movement (Suharko, 2005). The New Social Movement is a movement that emphasizes changes in lifestyle and culture rather than encouraging specific changes in public policy or economy (Nash, 2005).

This is confirmed by Scoot (1990) who states that environmental movements like Berlibur are an important component in the wave of "new social movements" that have swept through industrial society. This is because the main reason for success in maintaining and protecting the environment cannot be separated from the support of the community in general (Zeus \& Reif, 2007), where public support is an important resource for any social movement (Giugni, 1998).

In fact, it was not easy for the initiators of Berlibur to succeed every event in every kecamatan that had been scheduled since the beginning of program planning. However, technological development and social media became the main weapon to socialize and encourage people to participate in Berlibur as a new social movement. It is a pure program initiated by the environmentallyconcerned youth of $\mathrm{KBB}$, and since the beginning it has no funding for operation. The position of Rudy Praja, which is the admin of Instagram account @infokbb, is an advantage for the initiators to socialize their plans to all followers. In addition, they have a group in Facebook and they also send broadcast messages to all members of the group, which are also the members of every community in Lintas Komunitas KBB. Thus, they are easy to embrace and encourage the people of KBB to participate in their events. Community based initiatives and activities usually last in shorter time while the impact of it usually could be seen in longterm. The success of Berlibur in engaging its public in the now activities, need to be maintained to sustain public participation and the development of lifestyle as mentioned by Nash (2005). This article aims to look into the most important item that igniting public participation and engaging them to Berlibur, so that the research result could become empirical data in developing and enhancing the initiatives.

\section{LITERATURE REVIEW}

This study will discuss about how the members of Lintas Komunitas KBB led by Rudy Praja create a program called Berlibur, the acronym of bebersih keliling lembur, that inspires and motivates all people to be more concerned about the environment and contribute to solving the waste problem in KBB. Berlibur is a form of new social movement in environment. This study is in line with a study by Adityo Nugroho, i.e. Komunitas Muda Urban Mengelola Sampah 'Urban Youth Community Managing Waste': Kajian Partisipatoris Gerakan Peduli Sampah Nasional di Kota Yogyakarta 'Participatory Study on National Waste Management 
Movement.' Nugroho's study was conducted based on the emergence of several urban youth communities in Yogyakarta. They then collaborated with Aliansi Komunitas Yogyakarta 'the Alliance of Yogyakarta Communities' to initiate an environmental movement called Peduli Sampah Nasional 'National Waste Management' (PESAN) 2017.

The study describes how PESAN 2017 was aimed at improving people's awareness on the danger of waste that can harm environment and ecological balance. Using participatory approach and qualitative analysis, the study was conducted based on two events of the movement. PESAN 2017 was divided into two events. The first was aimed at educating high school (SMA) students about the importance of waste management. The second was an act of cleaning up waste in Kali Gajah Wong riverbanks. This event was also aimed at educating people who lived near the river of how managing sanitation and waste.

The results showed that through PESAN 2017, the educational, environmental movement initiated by Aliansi Komunitas Yogyakarta, it can be noticed that urban youth tended to actively respond any phenomenon around them. Collective action of urban youth certainly has its own story. If we look at environmental issues, surely every young urban community has its own views on how to behave. The adequate actions may include not littering, encouraging others to adopt a healthy lifestyle, going down to the center of environmental damage, or even being a vegetarian. Every urban youth community has the right to choose how they would contribute to environmental conservation. Thus, it became a remarkable event when every community of Aliansi Komunitas Yogyakarta put aside their own ego and went along to initiate a movement. These urban young men had shown a mature attitude.

New social movements occur in many countries, including in third world countries such as India. A research conducted by Dr. Bina Rai entitled New Social Movements in India: An Aspect of Environmental
Movements states that India faces problems of environmental degradation and lack of governance on matters related to these. The new social movements in the Third World show a rare sensitivity to the heterogeneity of the sources and structures of exploitation and oppression. The new social movements can be seen as vehicles of cumulative change in the social, economic and political fields. The role of these people's movements and experiments transcends not only state power, but also the new existing civil societies (Rai, 2015).

Another literature for the study on Berlibur was The Zero Waste Movement: A case study of mundane climate change activism in Denmark, a study by Mette K. Pedersen (Pedersen \& Mette, 2017). Pedersen conducted the study in order to complete his study on Master of Arts in Media and Communication Studies: Culture, Collaborative Media, and the Creative Industries in 2017, which was supervised by Jakob Svensson.

The study shows that there are new opportunities from social media to mobilize large groups of people to achieve a common goal, i.e. to take care of the Earth. In addition, there are also new forms of political engagement. This paper is a case study of activism in climate change by zero waste community in Denmark. In addition to framing theory (Goffman, 1974), this study also employed online observations of local Facebook groups and Instagram activity as well as in-depth interviews in order to understand how participants use social media to make their daily climate activism meaningful.

In this paper, the concepts of subactivism and mundane citizenship from Bakardjieva (2005) and framing theory are used to understand how mundane actions related to climate change are perceived meaningful by the participants of the Danish zero waste community. The study shows examples of how the participants of the Danish zero waste community use social media to make their mundane activism related to climate change meaningful 
for them. They use social media to get inspired, to share their experiences and to be a part of a community of climate change activism by doing mundane routines. By utilizing Facebook groups and Instagram for discussions, they create, challenge, and negotiate a collective action frame of the zero-waste movement. This in turn proves that the collective action is useful in encouraging and inspiring them to keep on doing small acts in their everyday life.

Many aspects of Berlibur, in fact, can be discussed here, but this paper will only discuss about how Berlibur as a new social movement can embrace many other communities to join in and succeed this cleanup program. As shown by Pedersen, social media has a great role in mobilizing people to achieve one specific goal. Without having to involve the government or any other agencies, Lintas Komunitas KBB is able to communicate with and encourage the youth across West Bandung to participate in Berlibur every month.

\section{METHODS}

The researchers used qualitative method with case study approach to obtain a comprehensive description about Berlibur. Case study allows the researchers to study and maintain the phenomena as a whole. The phenomena in question can be any events from real life such as one's life, organizational or managerial process, social change, etc. Case study is an empirical question that investigates phenomenon in real-life context if the boundaries between the phenomenon and the context do not appear explicitly, and it uses multi-source evidence (Yin, 2014). Using the approach, the researchers were enabled to explore a case, i.e. Berlibur-a new social movement in West Bandung, from time to time: from its initiation in the end of 2018 to the latest event in Kecamatan Padalarang in August 2019. The researchers collected detailed, in-depth data from various sources of information (Creswell, 2013).

In case study, a researcher studies as much data as possible about an individual, group, or event, so that they are able to provide a complete and in-depth view of the subject under study. Ragin adds that case study approach considers a case a whole entity, not a collection of parts nor aggregate scores about variables (Ragin in Mulyana, 2002: 203). Therefore, the nature of case study is holistic and multi-source. The researchers seek to collect data from many relevant sources.

Primary data of this study was collected through interviews with key informants, i.e. people who are considered knowing about the social situation/object under study (Sugiyono, 2016). In this study, the researchers interviewed Rudy Praja, the initiator of Berlibur, and local committees from Kecamatan Parongpong, Kecamatan Batujajar, and Kecamatan Padalarang. The three regions were chosen because Parongpong is the place of the first event, Padalarang is the place of the latest event, and Batujajar came in between. In addition to interviewing the initiators and the representatives of local committees, the researchers also interviewed several other parties, including some participants and a representative of environmental services of West Bandung.

Another data-collecting technique used by the researchers was observation, specifically participant observation. The researchers observed the events of Berlibur. They also observed social media utilized by the committees to socialize and promote the program. In addition to interview and observation, the researchers studied relevant literatures in order to analyze data collected from the field more accurately. Below is a picture that shows the existence of the researchers among the members of the communities in an event of Berlibur while conducting participatory observation for field data collection.

After collecting data from the field, the researchers analyzed them. The researchers used Miles \& Huberman's (1992) method, in which the first thing to do is data reduction. In this stage, the researchers selected data 
that were in accordance with what is needed to answer the research questions. In fact, the researchers obtained a lot of data. However, the data were mixed up between the relevant and irrelevant ones. Therefore, they have to reduce data. Then, they displayed the data in forms ofdescriptions, tables, or even diagrams to show the results. Finally, they conducted conclusion drawing and verification. During the research, every drawn conclusion would be continuously verified until a valid, solid conclusion is obtained (in Salim, 2001: 22). As of the writing of this paper, the research is still ongoing. Therefore, the conclusion of this study will be continuously verified until solid and valid.

\section{RESULTS AND DISCUSSION}

\section{The Origin of Berlibur}

Berlibur is a program initiated by the youth of West Bandung Regency who are concerned with social problems. Not only environmental problems, the initiators of Berlibur are also the youth who are aware of all problems and conditions in their hometown. They are the people who since the beginning have done many activities without depending on funders. They are independent people. With their own power and ability, they seek to solve social problems they see in their hometown.

In the beginning, Rudy Praja, an initiator and coordinator of Berlibur, was a young man who held many activities in West Bandung. He initiated Komunitas Ulin Jarambah 'Adventure Community', a community that encourages people to go together to many high-valued, untouched places, which are usually unknown to public and unattended by the government. The community was founded based on the fact that West Bandung has so many natural and cultural attractions, and wide community should know them and make them high-valued tourism attractions. The community also educates people on the natural and cultural legacy they have and makes them realize that it is a capital to develop their hometown.

In addition to Ulin Jarambah, Rudy
Praja also built Urang Bandung Barat 'People of West Bandung' (UBAR), another community. Just like Ulin Jarambah, UBAR is also concerned with tourism. However, it is slightly different from Ulin Jarambah. The focus of UBAR is promoting the unpromoted existing tourism attractions in KBB. Thus, the program is called Mengenal KBB 'Learning KBB.' The program was initiated because Rudy and friends learned that there were completely no promotion activities for West Bandung tourism. Hence, they initiated the community and the program.

In addition to social conditions in West Bandung, Rudy Praja is also aware of the development of technology. He believes that communication technology can be a great weapon to socialize every of his thought and activity. Along with the development of communication technology, Rudy utilizes social media to communicate every event held by his communities. He uses Twitter, Facebook, and finally Instagram. Rudy believes in the power of social media, especially Instagram. He created @infokbb, an account that informs every event in West Bandung. Instagram is the right media since the target of the messages is the youth, the millennial generation, of West Bandung. Thanks to @infokbb and Ulin Jarambah, Rudy is well-known among communities and young generation in West Bandung.

In 2018, Rudy was entrusted to hold many events in West Bandung to commemorate World Cleanup Day. During the WCD, he successfully embraced many other communities to be the local committees and many young men to participate in WCD 2018 in West Bandung. In turned out that during the WCD 2018 the committees could encourage 10,000 people to clean up 100 tons of waste. The following is a part of an interview with Rudy Praja:

I was interviewed by Pikiran Rakyat, a local newspaper. I said [there were] 3,000 men, according to the data from my colleagues. And the cleaned-up waste in every kecamatan was about 12-30 tons. So, I guess we cleaned up around 100 tons. That's only by the 
communities. Then I got news from $\mathrm{Bu}$ Umar (the head of environmental services of $K B B$ ), the participants were not only the communities. In villages the number of hansip (civil defense) and PKK women who participated in based on an instruction of the Regent was around 5,000, a large number, and the number of participants from communities was about 5,0oo. So, in total, there were about 10,000 people.

Based on the success of WCD events, Rudy and his friends in the committees felt that it's a pity if the garbage collection program was only held on certain days. They believed that it should be held on a regular basis. Finally, they agreed to continue the program, even though they had no funding. Their love to environment and concerns to social problems became the basis of the continuation of the program. As stated by Oriz (the nickname of the informant), who was the treasurer of WCD 2018 and is the secretary of Berlibur, it would bea pity if the rare movement was not continued. Sacrifices the committees made and the togetherness they built became a special motivation to continue the program on a regular basis. Hence, in the end of 2018, a new community was built from every community holding the WCD 2018. It's called Lintas Komunitas KBB 'All West Bandung Communities.' Lintas Komunitas KBB (Likom KBB) then created a program called berlibur a.k.a. bebersih keliling lembur 'Cleaning Up Our Surroundings.' The program is implemented for 1 year in 2019, and held in 16 kecamatan of West Bandung Regency.

\section{Berlibur as A New Social Movement in West Bandung Regency}

The beginning of Lintas Komunitas KBB with its program Berlibur shows that the movement, which is organized by Rudy Praja and several local youths with common view and goal, is a social movement. Herbert Blumer (1951) defines social movement as a collective action of a large number of people to create new life order or achieve common goals or objectives (Suharko, 2006). Social movement is also defined as a collective effort to achieve common interests, or a movement to achieve common goals through collective action outside established agencies (Giddens, 1993). Both definitions explicitly show that Berlibur 'Cleaning Up Our Surroundings', which was initiated by Lintas Komunitas $\mathrm{KBB}$ and is carried out by all people who feel the need to keep the environment clean, is a social movement. Without any interference from the authorities, the movement emerges as a collective effort to achieve a common interest, i.e. to keep the neighborhood clean.

In Berlibur, there is a collective action from many communities in West Bandung to achieve certain objectives, which are oriented to change, i.e. to improve the awareness of the importance of keeping the neighborhood clean and eradicating the bad habit of littering. The collective action of the independent organization is carried out in a certain period, i.e. monthly throughout 2019 (except June when the people fast during Ramadan). It needs to be emphasized again that Berlibur is extra-institutional or noninstitutional in nature, where no government agency's participation in the preparation of this program. The five aspects above meet the principle of social movement by Gerry van Klinken. According to him, a social movement should at least has three out of five categories: (1) there must be a collective action; (2) objectives or claims that are oriented to a change or order; (3) the collective action should be extra-institutional or noninstitutional in nature; (4) organization, to a certain degree; (5) continuity, to a certain degree of time (Klinken, 2007).

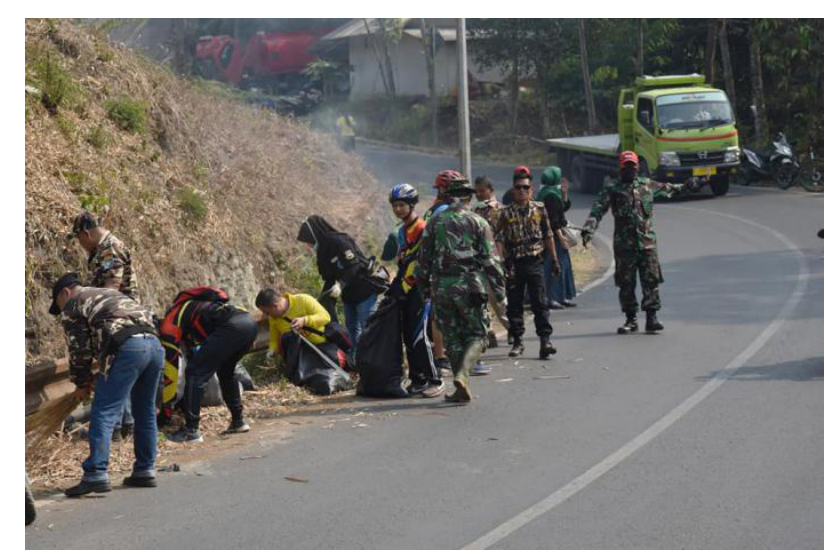

Figure 1 An Event of Berlibur

Source: Documentation of Lintas Komunitas $\mathrm{KBB}, 2019$ 
The social movement eventually transforms into new social movement, a new dynamic of the existing social movement. Berlibur is a movement classified into new social movement. New Social Movement is the repertoire of social movement (Pichardo, 1997). Programs in new social movement do not represent a small group fighting a narrow interest. It's different from social movement as well. It's not like a political party that aims at transforming social condition through political process (Abercrombie, 2010). New Social Movement usually emphasizes changes in lifestyle and culture rather than encouraging specific changes in public policy or economic change like environmental, anti-war and peace, feminism movements, etc. (Nash, 2005). Phicardo (1997) and Singh (2001) state that there are salient characteristics of new social movement: (1) ideology and objective; (2) tactics and organization; (3) structure, (4) participant or actor (Suharko, 2006).

In terms of ideology and objective, new social movement raises the issue of community and society "defense" against the increasing expansion of the state and the market. The most obvious expression is the emergence of social agents fighting for social supervision and control, and one of them is environmental activist. In regard to Berlibur, the initiators of the program are environmental activists who are highly aware of the unsolved waste problem, in spite of many programs of government agencies.

In terms of tactics and organization, new social movement tends to choose any channels other than formal politics. According to Cohen, new social movement generally responds issues of civil society rather than economy and state (Suharko, 2006). In regard to Berlibur, the issue is environment, where the initiators notice that the waste management of West Bandung's government agencies has not given a significant impact. In fact, it can be said that waste problem is getting worse, where piles of garbage can be easily found in protocol roads in West Bandung. Therefore, in conducting its activities, Berlibur technically uses any channels other than formal politics. The program is purely from, implemented by, and for the people of West Bandung.

In term of structure, new social movement seeks to build a desired structure, where they can organize themselves in a flexible style. Berlibur as a new social movement always rotates its leadership, where every region has their own committee and ad hoc team to coordinate the program there. There is no central leadership, even though they have a main coordinator for all activities throughout West Bandung. They don't develop a form of bureaucracy, but rather a more responsive structure that can meet individual needs, i.e. an open, decentralized, non-hierarchical structure.

In terms of participant or actor, the participants of Berlibur is from many communities beyond social categories like gender, education, occupation, and class. The actors of Berlibur seek to cross social barriers in the interest of humanity (Singh, 2001). They are included in a group that is free from the motive of profit since most of them are the educated ones, such as activists, artists, students, and academics. This is evidenced from the actors who actively succeed the program. Oriz, an informant and the secretary of Lintas Komunitas KBB, stated that he took part in it because it focuses on social, not business. He admitted that he wouldn't want to involve if it's economy-oriented.

As a new social movement, Berlibur can be classified as public environmentalist, where the event organizers and participants seek to fix the neighborhood they live in through their actions and attitudes. This is in line with what is stated by a number of American environmental sociologists that environmental movement in a country can be divided into three components: public environmentalist, organized environmentalist or voluntary environmentalist, and institutional environmental movement organization (Aditjondro, 2003). 


\section{The Utilization of Social Media in Berlibur Program}

Strategies are needed to succeed Berlibur. One of them, one that should be arranged and implemented by the initiators, is communication strategy to socialize the new social movement. The main target of Berlibur is the youth of every communities in West Bandung Regency. Therefore, to socialize the program, social media is used as communication media. Communication activities of the initiators in social media is a strategy of the movement. As stated by Chandler, strategy is setting long-term goals and adjectives, as well as direction of action and resource allocation to achieve the goals and objectives (Singh, 2001). The use of social media to socialize Berlibur is intentionally set as a resource allocation to achieve the goals of the movement. As a strategy, activities in social media are proven to be capable of influencing the real movement (Donk et al., 2004).

Berlibur as a new social movement must be able to encourage people to be involved in this monthly program. Program socialization must be addressed to all people across the regency. Social media has been a device that is used by the actors to spread information, to persuade, and to consolidate with the participants of the program in many locations. The kinds of social media they use to socialize the program are social network and instant messaging. In term of social network, they use Instagram and Facebook, while in term of instant messaging they use WhatsApp, specifically its group feature.

The fruitfulness of social media in the implementation of communication strategy of Berlibur as a new social movement is inseparable from the main characters of social media. They are forms, contents, and characters of social media users (Porta, 2013). Each form of social media can mobilize supports if it's used properly according to its character and main function. In the socialization of Berlibur, social media they use are Facebook and Instagram. The main Instagram accounts of Berlibur committee are@lintaskomunitaskbb and @infokbb, whereas in Facebook, the committee uses a group: Lintas Komunitas KBB. As the nature of social media, information in Instagram and Facebook is only disseminated in (virtual) friendship networks. Hence, those who receive and redistribute the message are those who are interested and believe in the creators of the message, i.e. their own (virtual) friends. The creators of the message in Berlibur is Rudy Praja, the initiator, and the core committee, i.e. Lintas Komunitas KBB.

The second character of social media that succeeds the communication strategy is the contents of the message that are able to touch the emotion of the audience. Message strategy applied by the initiators is emotional appeal. Emotional appeal is a kind of message that uses touching statements. It comprises things related to lust, anger, suffer, fun, fear, and anxiety (Rakmat, 2018). According to Tan, it takes into account the feelings of the recipients based on feel and emotion, and it uses them to make the recipients pleased (Jamiluddin, 2005).

The form of messages disseminated in Instagram and Facebook is visual, i.e. posters of the program with a caption about the event to hold. In addition to informing events of Berlibur, the two social media are also used to persuade people to participate in the events. The characteristic of Instagram and Facebook, which allows the users to directly interact through comment column, is used by the initiators to make information "booming," or "ramékeun" in Sundanese. The initiators comment reciprocally and seek to touch the emotion of the audience so that they would be encouraged to participate in the program. In fact, the bidirectional communication in the comment column eventually can build an image that every community in KBB that don't participate in this program is not a cool community. This was stated by Rudy Praja, the initiator of Berlibur, when he was interviewed by the writers.

Well, it can be said that an unparticipating community is not a cool community. 
So, it also can be said that environment is cool, And I promote in social media that environmental care is also cool. Thus, many people sign up. Like those from the badimage mass organizations. Gibas, Sundawani Wirabuana, and BBC, they all registered, as well as the gangsters from XTC, Brigez, and Moonraker.

The persuasive messages conveyed and built by the initiators to make Berlibur viral in many platforms of social media can touch the emotion of the recipients. Aaker and Mayer (1982) state that emotional-appeal message uses mainly two approaches: psychological and sociological. Psychological approach usually refers to the needs of audience for satisfaction and personal state of feeling, such as happiness, security, compassion, affection, sadness, nostalgia, and so on. While sociological approach refers to the needs for status or acknowledgment (social based feeling), such as recognition, pride, acceptance, respect, and so on (Jamiluddin, 2005). The two approaches have been applied successfully by the actors of the new social movement Berlibur. The participants state that they're satisfied by participating its monthly event. It's all because they feel joy when they're involved in the effort to clean up the environment from pile of waste. In addition, they admitted that they're emotional when they successfully cleaned up large amounts of waste and finally see a clean environment. Besides, sociologically they feel proud and accepted as a community that cares about the environment. They think that their status as a part of the community can be lifted by participating in the new social movement.

Finally, the characters of audience or social media users become the main character of social media that is able to succeed the socialization and publication of Berlibur. The users of social media are the ones that will fully consider and assess information (Porta, 2013). A sense of solidarity and empathy arises when they see a problem in their environment, which in this case is a poor waste management problem. Waste is strewn on the protocol streets in
West Bandung Regency. As the native youth of West Bandung, they then have a shared identity built through content exposure from the actors of change of Berlibur. After successfully bringing out a sense of solidarity and empathy among community members that care about environment, the message then brings out an attitude in the audience that "I can make a change. I can change at least small things in the circle of my community." Changes by the community members include making their surroundings clean from waste and giving a concrete example to the people in their respective regions that they finally want to keep the environment clean.

\section{CONCLUSION}

The use of social media and the selection of emotional appeal in the content strategy are proven to be capable of motivating audience, i.e. the members of communities in West Bandung, to participate in Berlibur. A strong emotional bond between the members of communities that have participated in the social change program finally can make the members to keep on keeping the environment clean in their surroundings and encourage people in their own regions to do the same thing by at least not littering. The success of the social media utilization must be kept by the actors of change in order to make the involved members tied to the new social change movement. The intensity of communication must be well-maintained, either in social media or in the real life. Increasing the number of informal face-to-face meetings in the real life can be a way to maintain the involvement of all participants so that they will continue to support Berlibur, the new social movement.This research is still limited to the use of social media in making Berlibur movement successful. As a new social change movement, there are several other things that support the success of this program, including the use of organizational communication patterns, leadership styles, the role of opinion leaders, and community development. Some of them can be an 
interesting study for future researchers by conducting qualitative research. In addition, examining the effect of this program on increasing awareness of environmental hygiene would be a very interesting quantitative study in the future.

\section{ACKNOWLEDGEMENT}

The study on Berlibur program can be well-conducted due to the openness of Lintas Komunitas Kabupaten Bandung Barat led by Kang Rudy Praja. Therefore, the researchers would like to thank all members of Lintas Komunitas (Likom) KBB that have provided many data through interviews and participatory observation in several events of Berlibur and direct observations on social media they use to socialize the program.

\section{REFERENCES}

Abercrombie, N. (2010). Kamus sosiologi. Yogyakarta: Pustaka Pelajar.

Badan Pengembangan dan Pembinaan Bahasa. (2016). KBBI Daring. Retrieved August 8, 2019, from Kementerian Pendidikan dan Kebudayaan Republik Indonesia website: https://kbbi. kemdikbud.go.id

Bakardjieva, M. (2005). Internet society: The internet in everyday life. London: Sage Publications.

Creswell, J. W. (2013). Qualitative inquiry E research design: Choosing among five approaches. Thousand Oaks: Sage.

Donk, W. van de, Brian, D. L., G.Nixon, P., \& Rucht, D. (2004). Cyberprotest: New media, citizens, and sosial movement (1st ed). London: Routledge

Giddens, A. (1993). Sociology. Cambridge: Polity Press.

Giugni, M. G. (1998). No title"Was it worth the effort? The outcomes and consequences of social movements. Annual review of sociology, 24(1), 371-393. https://doi.org/https://doi. org/10.1146/annurev.soc.24.1.371
Goffman, E. (1974). Frame analysis: An essay on the organization of experience. NewYork: Harper \& Row.

Jamiluddin, R. M. (2005). Tipologi pesan persuasif. Jakarta: Indeks.

Klinken, G. van. (2007). Perang kota kecil: kekerasan komunal dan demokratisasi di Indonesia. Jakarta: Yayasan Obor.

Maharsi, J. (2019). Berlibur ala komunitas di Bandung Barat, jaring 6 ton sampah di Curug CImahi. Retrieved from https:// komunita.id/2019/o1/o7/berlibur-alakomunitas-di-bandung-barat-jaring-6ton-sampah-dari-curug-cimahi/

Nash, J. (2005). Social movements, an anthropological reader. Oxford: Blackwell Publishing Ltd.

Nugroho, A. (2017). Komunitas muda urban mengelola sampah: Kajian partisipatoris gerakan peduli sampah nasional di Kota Yogyakarta. Jurnal Pemikiran Sosiologi, 4(1), 106-119. Retrieved from file://D:/DISERTASI/ Gerakan Sosial/23633-46307-1-SM.pdf

Pedersen, K., \& Mette. (2017). Digital ethnography and critical discourse analysis of the zero waste movement on social media. In Malmo University Electric Publishing. Malmo University.

Pichardo, N. A. (1997). New social movements: A critical review. Annual review sociology, $23(1)$.

Porta, D. (2013). Can democracy be saved? Participation, deliberation, and social movement. Cambridge, UK: Polity Press.

Rai, B. (2015). New social movements in India: An aspect of environmental movements. International Journal of Science and Research (IJSR), 4(9), 19181921.

Rakhmat, J. (2018). Psikologi komunikasi (Revision; T. Surjaman \& R. K. Soenendar, Eds.). Bandung: Simbiosa Rekatama Media. 
Sari, C. W. (2019). Berlibur, aksi bersih-bersih sampah KBB. Retrieved from https:// www.pikiran-rakyat.com/bandungraya/2019/o8/28/berlibur-aksi-bersihbersih-sampah-kbb

Scott, A. (1990). Ideology and the new social movements. UK: Unwin Hyman.

Singh, R. (2001). Social movements, old and new, a post-modernist critique. New Delhi: Sage Publication.

Sugiyono. (2016). Memahami penelitian kualitatif. Bandung: Alfabeta.

Suharko. (2005). Merajut demokrasi, hubungan NGO, pemerintah, dan pengembangan tata pemerintahan demokratis (1966-2001). Yogyakarta: Tiara Wacana.

Suharko. (2006). Gerakan sosial baru di Indonesia: Repertoar gerakan petani. Jurnal Ilmu Sosial Dan Ilmu Politik, 10(1-34). https://doi.org/https://doi. org/10.22146/jsp.11020

Yin, R. K. (2014). Studi kasus: Design dan metode. Jakarta: Raja Grafindo Persada.

Zeus, J. H., \& Reif, K. (2007). Evolution of environmental attitudes in the European community. Scandinavian Political Studies, 13(2), 119-146. https:// doi.org/10.1111/j.1467-9477.1990. tboo433.x 